\title{
Species co-occurrence and management intensity modulate habitat preferences of forest birds
}

\author{
Marco Basile ${ }^{1,2,3^{*}} \mathbb{D}$, Thomas Asbeck $\mathbb{B}^{\mathbb{D}}$, João M. Cordeiro Pereira ${ }^{1} \mathbb{B}$, Grzegorz Mikusiński ${ }^{1,5,6}$ and Ilse Storch ${ }^{1}$
}

\begin{abstract}
Background: Species co-occurrences can have profound effects on the habitat use of species, and therefore habitat structure alone cannot fully explain observed abundances. To account for this aspect of community organization, we developed multi-species abundance models, incorporating the local effect of co-occurring and potentially associated species, alongside with environmental predictors, linked mainly to forest management intensity. We coupled it with a landscape-scale analysis to further examine the role of management intensity in modifying the habitat preferences in connection with the landscape context. Using empirical data from the Black Forest in southern Germany, we focused on the forest bird assemblage and in particular on the cavity-nesting and canopy-foraging guilds. We included in the analysis species that co-occur and for which evidence suggests association is likely.

Results: Our findings show that the local effect of species associations can mitigate the effects of management intensity on forest birds. We also found that bird species express wider habitat preferences in forests under higher management intensity, depending on the landscape context.
\end{abstract}

Conclusions: We suspect that species associations may facilitate the utilization of a broader range of environmental conditions under intensive forest management, which benefits some species over others. Networks of associations may be a relevant factor in the effectiveness of conservation-oriented forest management.

Keywords: Canopy forager, Cavity nester, Landscape, Multi-species abundance models, Forest management intensity, Temperate forests

\section{Background}

Species assemblages form as a product of environmental filtering (i.e., local environmental conditions acting as filters for local species sorting) and species interactions [1]. In forest ecosystems, environmental filtering depends, among other factors, on the main tree species, which can be subject to spatial and temporal variation

\footnotetext{
* Correspondence: marcob.nat@gmail.com

'Chair of Wildlife Ecology and Management, University of Freiburg,

Tennenbacher Str. 4, 79106 Freiburg, Germany

${ }^{2}$ Swiss Federal Research Institute WSL, Zürcherstrasse 111, 8903 Birmensdorf, Switzerland

Full list of author information is available at the end of the article
}

[2]. Trees may alter the biotic conditions and modulate the access to resources for other species. For instance, trees can modify the amount of light that reaches lower forest layers and profoundly impact the plant species composing the herb layer [3] or change micromorphological and chemical soil properties and greatly affect soil organisms [4]. Similarly, the occurrence and abundance of forest-inhabiting taxa such as bats, birds or insects may depend on tree structures such as rot holes and cavities providing resources to them [5-7].

In contrast, species interactions are based on intraand interspecific competition for resources [8], along with other trophic interactions such as predation [9] or

(c) The Author(s). 2021 Open Access This article is licensed under a Creative Commons Attribution 4.0 International License, which permits use, sharing, adaptation, distribution and reproduction in any medium or format, as long as you give appropriate credit to the original author(s) and the source, provide a link to the Creative Commons licence, and indicate if changes were made. The images or other third party material in this article are included in the article's Creative Commons licence, unless indicated otherwise in a credit line to the material. If material is not included in the article's Creative Commons licence and your intended use is not permitted by statutory regulation or exceeds the permitted use, you will need to obtain permission directly from the copyright holder. To view a copy of this licence, visit http://creativecommons.org/licenses/by/4.0/ The Creative Commons Public Domain Dedication waiver (http://creativecommons.org/publicdomain/zero/1.0/) applies to the data made available in this article, unless otherwise stated in a credit line to the data. 
facilitative interactions [10]. Species interactions are often simplistically assumed based on patterns of species co-occurrences, in relation to a baseline occurrence rate dependent on the environmental conditions [11]. Despite criticism to this approach [12], the inclusion of an interaction component can indeed improve the outcome of ecological niche modeling [13]. In this context, however, interactions are reduced to co-occurrences, which may, in turn, be non-random and linked to unknown processes which cause species associations. Yet the effect of interacting species can modify ecological niches within populations, highlighting inter-individual differences [14], or differences within meta-populations, e.g., following the introduction of allochthonous species [15].

The concomitance of biotic and abiotic factors and processes shapes the ecological niche of species, described as the Hutchinsonian niche [16, 17]. This is further modulated by anthropogenic influences that often elicit different local responses within species' distribution ranges, frequently leading to niche contraction and population decline when anthropogenic disturbance is dominant [18]. In the case of forests, forestry can be a fundamental determinant of the habitat use for forest species, hence altering their ecological niche [19]. Birds are affected by forestry operations at the level of individuals, populations, and communities, through habitat simplification, which deprives birds of important resources such as suitable nest sites or food supply [2023]. However, landscape characteristics can contribute to alter the realized niche, despite the habitat conditions. For instance, the degree of forest fragmentation can affect the ability of species to spill over into suboptimal habitat types, a density-dependent process also influenced by regional abundances [24]. This often results in local niche contractions [24], as the overall breadth of the realized niches is related to the ability of species to cope with the landscape context and colonize different habitat patches $[25,26]$.

Some of the bird species most affected by forestry belong to the cavity-nesting guild [27], which is composed by primary cavity nesters, i.e., those bird species that excavate their own cavities in trees, and secondary cavity nesters, i.e., those that use cavities generated by natural processes or excavated by primary cavity nesters [28]. The substrate (trees and snags with specific characteristics) where the cavity is located may trigger competitive interactions among species $[29,30]$. Experimental evidence indicates that the supply of cavities can limit the number of cavity nesters [28, 31]. Forest management for timber production is considered one of the main causes of shortages in cavity supply [32], usually reflected by a relative decline of the cavity-nesting guild within the bird assemblage [27]. The main reason is that such management leads to a shortage of trees or snags with characteristics enabling formation of natural cavities or allowing their excavation by primary cavity nesters [33]. This is in contrast to primeval forests with plentiful decay-formed cavities, where the abundance of nest sites is not a limiting factor for cavity nesters and woodpeckers are not always the key cavity providers [34]. Hence, in managed forests species-specific responses to forestry operations might show a high degree of variation depending on the relative abundance of large, suitable trees, and snags offering the potential to provide cavities $[35,36]$, the relative abundance of woodpeckers [37], the forest management type [38], and the tree species composition [39]. Moreover, the predation risk $[40,41]$ and the presence of invasive species [42] are additional factors shaping the cavity-nesting bird guild. Considering all those factors, we could expect that the abundance of cavity nesters is regulated by the relative abundance of each species included in this guild, via competition for resources, interference, facilitation, or to a lesser extent, predation.

Another bird guild highly influenced by forestry is the canopy-foraging guild [43-45], which includes those species that feed on substrates in the tree canopy [46]. In this case, competition sparks from the optimal foraging substrate (e.g., large branches vs. small branches with needles in conifer canopy) and the different efficiency of each species' foraging technique [47-49]. In Europe, it comprises mainly foliage gleaners and seed eaters. In the case of canopy foragers, the main interaction we could expect is resource competition, where the presence of a given species reduces the foraging efficiency of its competitors.

In this study, we combined local species abundances and habitat modeling, using local and landscape features, to understand how forest management intensity influences the response of co-occurring species to the environment. Specifically, we aimed at answering two questions: (1) how does species co-occurrence influence species' habitat selection and (2) how does forest management intensity modify species' habitat selection in different landscape contexts?

Many forest species are negatively impacted by intensive forest management [50-53] but can still persist in situations where interspecific interactions allows them to diversify their habitat use [54-56]. We relied on multispecies modeling to incorporate interspecific interactions [11] and restricted our analysis to cavity-nesting and canopy-foraging bird species, which allowed us to assume direct interspecific interactions concerning nesting and foraging sites during the breeding season. In this way, we could account for possible associations among species (as for research question 1), and for those species directly relying on structures which are influenced by forest management (as for research question 2). We 
modeled the abundance responses to the environment of co-occurring and potentially associated birds of the cavity-nesting and canopy-foraging guilds, accounting for habitat structure, management intensity, availability of tree-related microhabitats (TreMs) [57], and landscape composition. We expected that the response of each species to the habitat structure in presence of associated species would deviate from the responses excluding association among species. Although this would not allow us to determine causal links, it may indicate the presence of an effect, signaled by the direction and magnitude of the correlations between species' abundances. Regarding the landscape context, we expect that in suboptimal landscapes, species will broaden their habitat choice where management intensity is higher, as a result of higher occurrence rates in suboptimal sites.

\section{Results}

\section{Guilds abundance and associations}

Over 3 years, we recorded 8812 individuals belonging to 16 different species that were detected at least 30 times, of which 11 were cavity nesters, 10 canopy foragers, with 5 belonging to both guilds (Table 1 ). The most common species counted at plots was the coal tit (Periparus ater), with an average number of individuals per plot and visit of $0.93( \pm 0.84 \mathrm{SD})$, while the short-toed treecreeper (Certhia brachydactyla) was the least common (0.02 \pm $0.17 \mathrm{SD})$. The multi-species model included 77 assumed associations between the 16 species (figure S1). Species that were not influenced by other species included woodpeckers, large-sized species (e.g., stock dove $\mathrm{Co}$ lumba oenas), species that can substantially rely on other resources (e.g., blackcap Sylvia atricapilla forage also in shrubs), or species that can escape competition by various means (e.g., European nuthatch Sitta europaea can substantially modify the cavity opening). The mean probability of detection across all species was 0.18 , ranging from $0.03( \pm 0.69 \mathrm{SD})$ of the blackcap to 0.51 ( \pm $0.55 \mathrm{SD}$ ) of the great tit (Parus major). All 16 species responded in abundance to at least one forest variable, reporting a credible estimate $(f>0.9)$, while for ten species the effect of the forest management intensity index scored a credible and negative estimate (Table 1). Cooccurring species scored credible effect estimates with up to four other species, totaling between the two guilds 22 credible associations, out of the 77 hypothesized (Fig. 1). Statistical associations indicated thirteen negative and nine positive effects between two species. Three species, the great tit, the marsh tit (Poecile palustris), and the short-toed treecreeper, returned only one association, while four associations were found for the blue tit (Cyanistes caeruleus).

\section{Habitat characterization}

For the entire studied assemblage, we did not find differences in abundance along the gradients of forest variables, when including species associations in the abundance model (Fig. 2). Along the altitudinal gradient, the abundances were also similar in both models, although the model without associations presented a rather positive response to altitude, due to the high abundances estimated for the coal tit. However, absolute abundances per species and plot covered a larger environmental gradient in the model accounting for associations: abundances were spread along a larger ForMI gradient (Fig. 3). This was particularly evident for the crested tit (Lophophanes cristatus) and the Eurasian treecreeper (Certhia familiaris), despite both having negative associations with other species.

Based on the forest variables identified as abundance predictors, the hierarchical clustering identified 79 plots as belonging to high management intensity class (HMI) plots, with means of basal area $=35.66( \pm 7.87 \mathrm{SD})$, conifer share $=0.76( \pm 0.20 \mathrm{SD})$, ForMI $=1.47( \pm 0.36$ $\mathrm{SD})$, TreM richness $=8.04( \pm 2.72 \mathrm{SD})$, and TreM abundance $=30.38( \pm 14.39 \mathrm{SD})$. Low management intensity (LMI) plots were 48 with means of basal area $=37.88( \pm$ 12.64 SD), conifer share $=0.51( \pm 0.25 \mathrm{SD})$, ForMI $=$ $0.78( \pm 0.44 \mathrm{SD})$, TreM richness $=14.5( \pm 4.49 \mathrm{SD})$, and TreM abundance $=67.4( \pm 48.41 \mathrm{SD})$. Altitudinal distribution was similar between management intensity classes. Landscape variables were not correlated with management intensity classes, with all perMANOVAs scoring $p>0.05$.

The PCA of the landscape variables for high abundance (HA) landscapes of the entire bird assemblage could explain $\sim 63 \%$ of the observed variation. The first component scored positive loadings for aggregation index, forest and conifer forest cover, and negative loadings for edge density and landscape shape index. This suggests that high abundances are observed in landscapes with large, contiguous forest patches (Table 2). Low abundance (LA) landscapes differed in the loadings of contiguity index, core area, forest, and conifer forest cover. This indicates that low abundances are to be found in landscapes with less forest cover and smaller forest patches. In this case the variance explained was $61 \%$ (Table 2). Confidence ellipses showed that the bird assemblage of HA landscapes occurred in HMI and LMI plots with a similar landscape structure. In contrast, LMI plots from LA landscapes were characterized by bird assemblages occurring in narrower landscape condition than HMI plots. This indicates that the assemblage occurred across a wider set of landscape conditions in suboptimal landscapes under high management intensity (Fig. 4). By looking at the position and width of the confidence ellipses for the single species, a similar pattern 


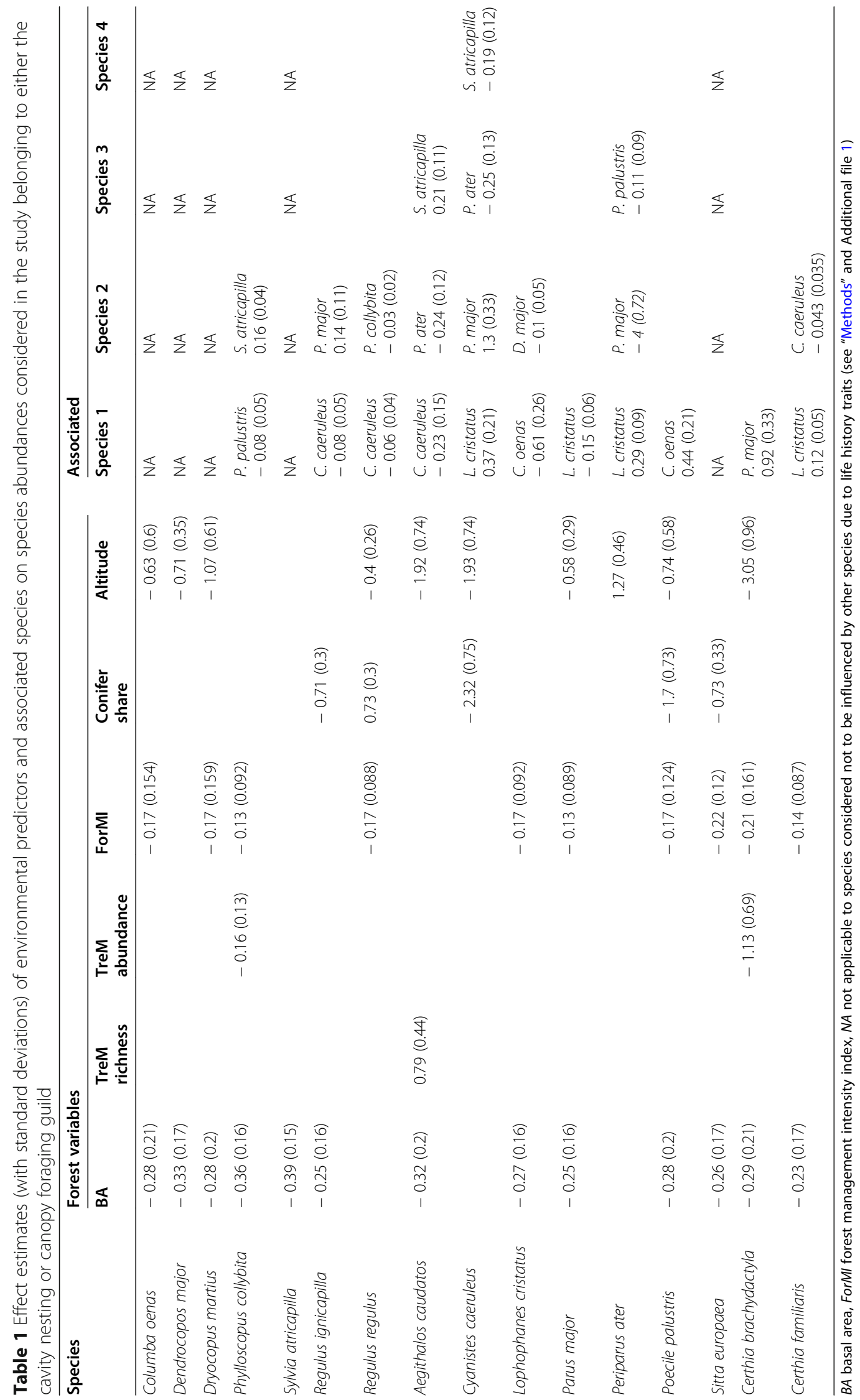




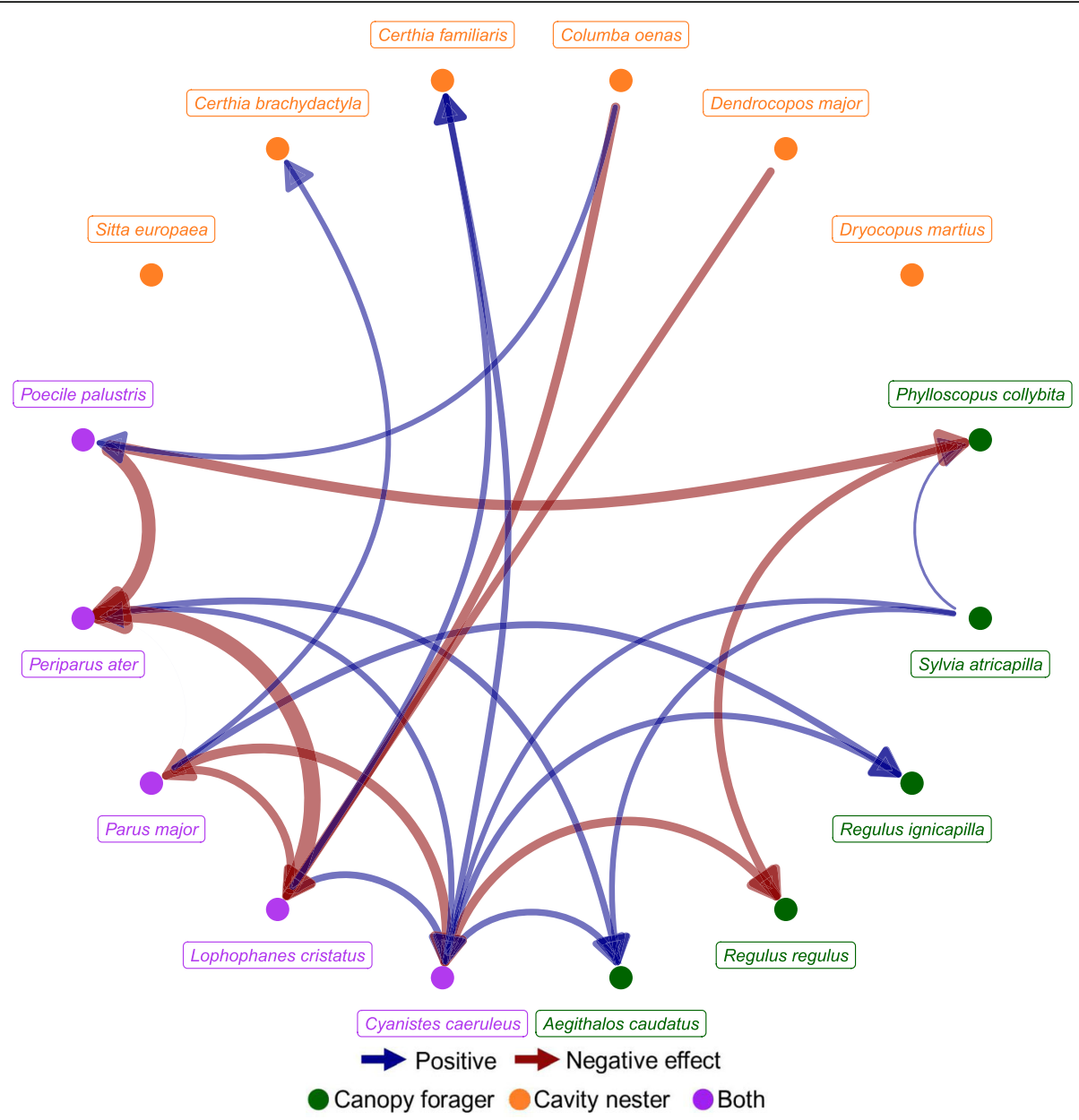

Fig. 1. Statistical associations among species found by modeling species abundances as a function of co-occurring species and environmental predictors. Twenty-two positive and negative associations were found. Associations are considered as density-dependent effects on the abundance of the influenced species, possibly due to interspecific competition over, in this case, nesting and feeding resources. Arrow width indicates the effect size

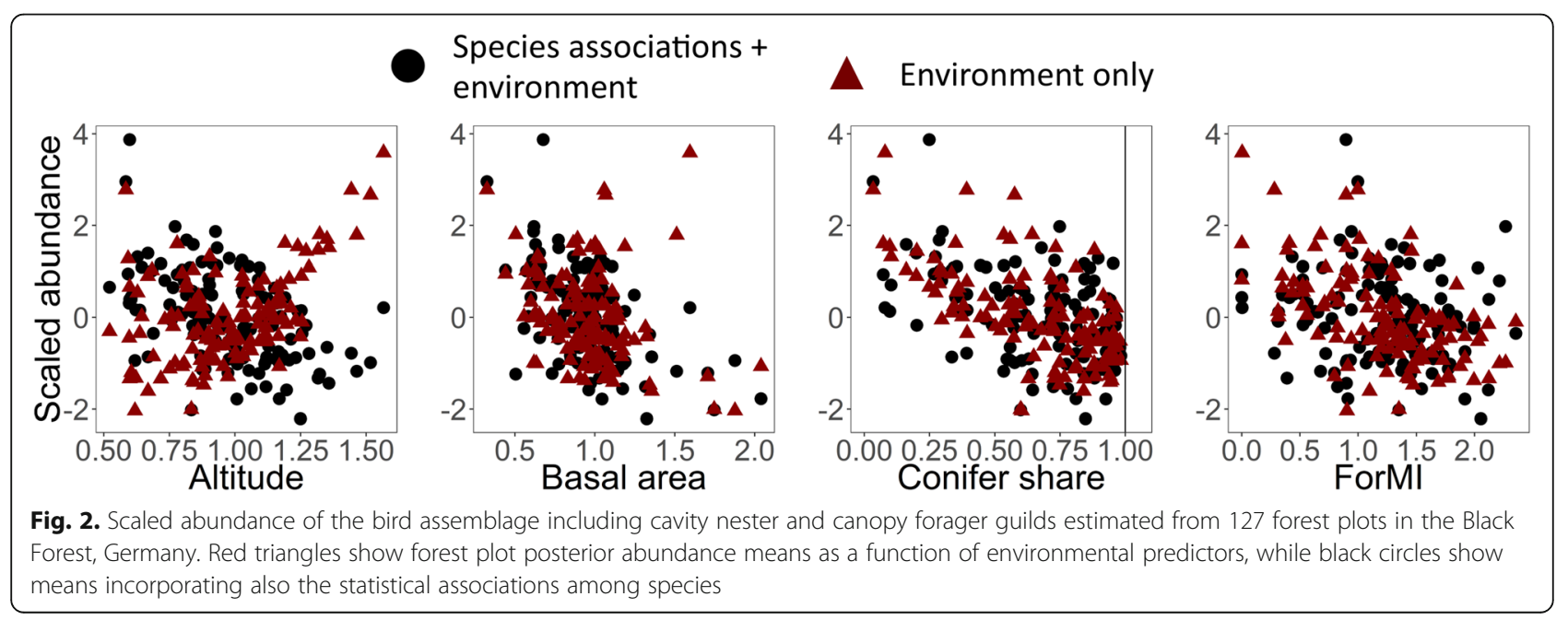



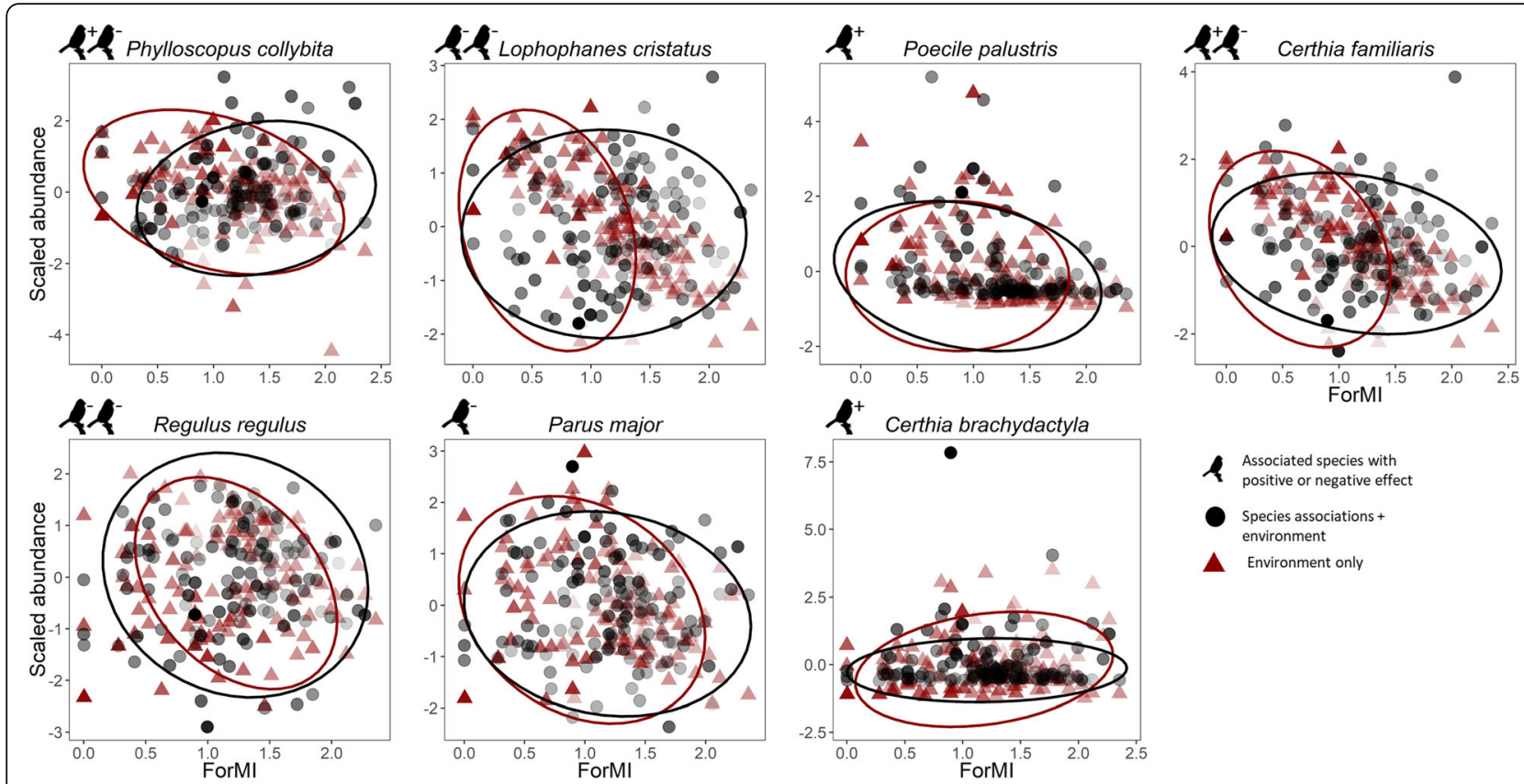

Environment only

Fig. 3. Scaled abundance of the species influenced by forest management intensity index (ForMI). Red triangles show forest plot posterior abundance means as a function of environmental predictors, while black circles show means incorporating also the statistical associations among species. 95\% ellipses coded with same colors encircle the section along the environmental gradient where the upper quartile of the abundances occurs. Bird icons indicate the number of associated species with positive (+) and negative (-) effects

was observed within the cavity-nesting and canopyforaging guilds, especially among those showing species associations (Figs. 5, 6, and 7). Specifically, Eurasian treecreeper (Certhia familiaris), chiffchaff (Phylloscopus collybita), European blackcap (Sylvia atricapilla), firecrest (Regulus ignicapilla), goldcrest (Regulus regulus), blue tit (Cyanistes caeruleus), and coal tit (Periparus ater) occurred over a broader range of landscape conditions in HMI plots located in LA landscapes. Among the other species, stock dove (Columba oenas) and marsh tit (Poecile palustris) showed an opposite pattern, with broader ranges of landscape conditions in HMI plots from HA landscapes. The woodpeckers (Dendrocopos major and Dryocopus martius), short-toed treecreeper (Certhia brachydactyla), great tit (Parus major), and crested tit (Lophophanes cristatus) used broader ranges of landscape conditions in HMI plots for both landscape categories. Finally, the occurrence patterns of European nuthatch (Sitta europaea) and long-tailed tit (Aegithalos caudatus) were similar in all landscapes.

Table 2 Factor loadings of the first two components (PC) of the principal component analysis on the landscape variables for high abundance (HA) and low abundance (LA) landscapes. Variance explained by each component is in brackets

\begin{tabular}{lllll}
\hline Landscape variable & HA landscape & & & LA landscape \\
\cline { 2 - 3 } & PC1 (44.43 \%) & PC2 (18.20 \%) & PC1 (46.29 \%) & PC2 (14.93 \%) \\
\hline Aggregation index & 0.49 & 0.06 & 0.46 & -0.30 \\
Contiguity index & 0.01 & -0.68 & 0.12 & -0.41 \\
Core area & 0.26 & -0.53 & 0.31 & 0.08 \\
Edge density & -0.41 & 0.09 & -0.43 & -0.25 \\
Euclidean nearest neighbor distance & -0.17 & 0.41 & -0.16 & 0.43 \\
Landscape shape index & -0.50 & -0.07 & -0.47 & -0.27 \\
Forest cover & 0.32 & 0.23 & 0.29 & -0.56 \\
Conifer forest cover & 0.37 & 0.11 & 0.41 & -0.30 \\
\hline
\end{tabular}



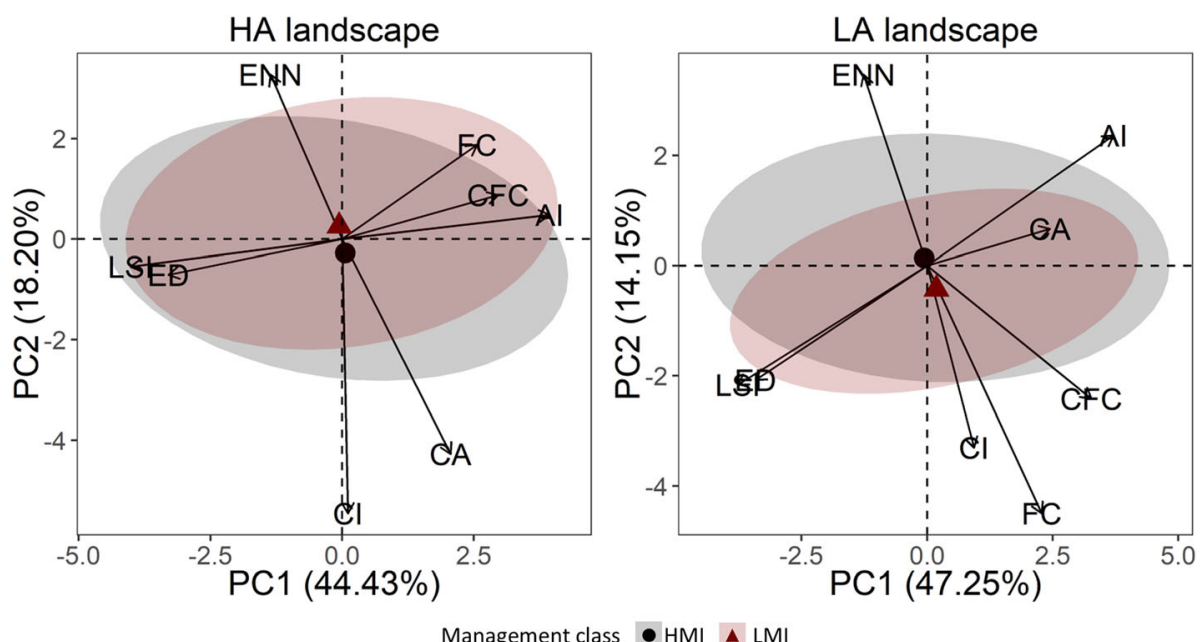

Fig. 4. Multivariate space of the bird assemblage of the Black Forest, Germany, including cavity nesters and canopy foragers, for high (HA) and low (LA) abundance landscapes. Arrows identify the relative landscape variables used to build the PCA axis. Numbers on axis represent the variance explained by the principal components. High management intensity (HMI) and low management intensity (LMI) plots are determined by a hierarchical clustering on forest variables and visualized with 95\% confidence ellipses, including the centroids. Al, aggregation index; CA, core area; Cl, contiguity index; CFC, conifer forest cover; ED, edge density; ENN, Euclidean nearest neighbor; FC, forest cover; LSI, landscape shape index

\section{Discussion}

\section{Habitat use of co-occurring species}

The role of interspecific associations in modulating how species use their habitat depends on the context in which they occur. Environmental, spatial, temporal, or community settings may all alter the magnitude and direction of such associations [58]. Large-scale environmental drivers have previously been linked with alterations in species association and co-occurrence patterns [59]. In our study, using forest birds, we demonstrated that the occurrence and abundance of species at a small (plot level) spatial scale are linked to local environmental drivers and, simultaneously, to co-occurring species. Hence, we observed a context-dependent change in habitat selection of species. Although our approach did not identify interactions empirically confirming the

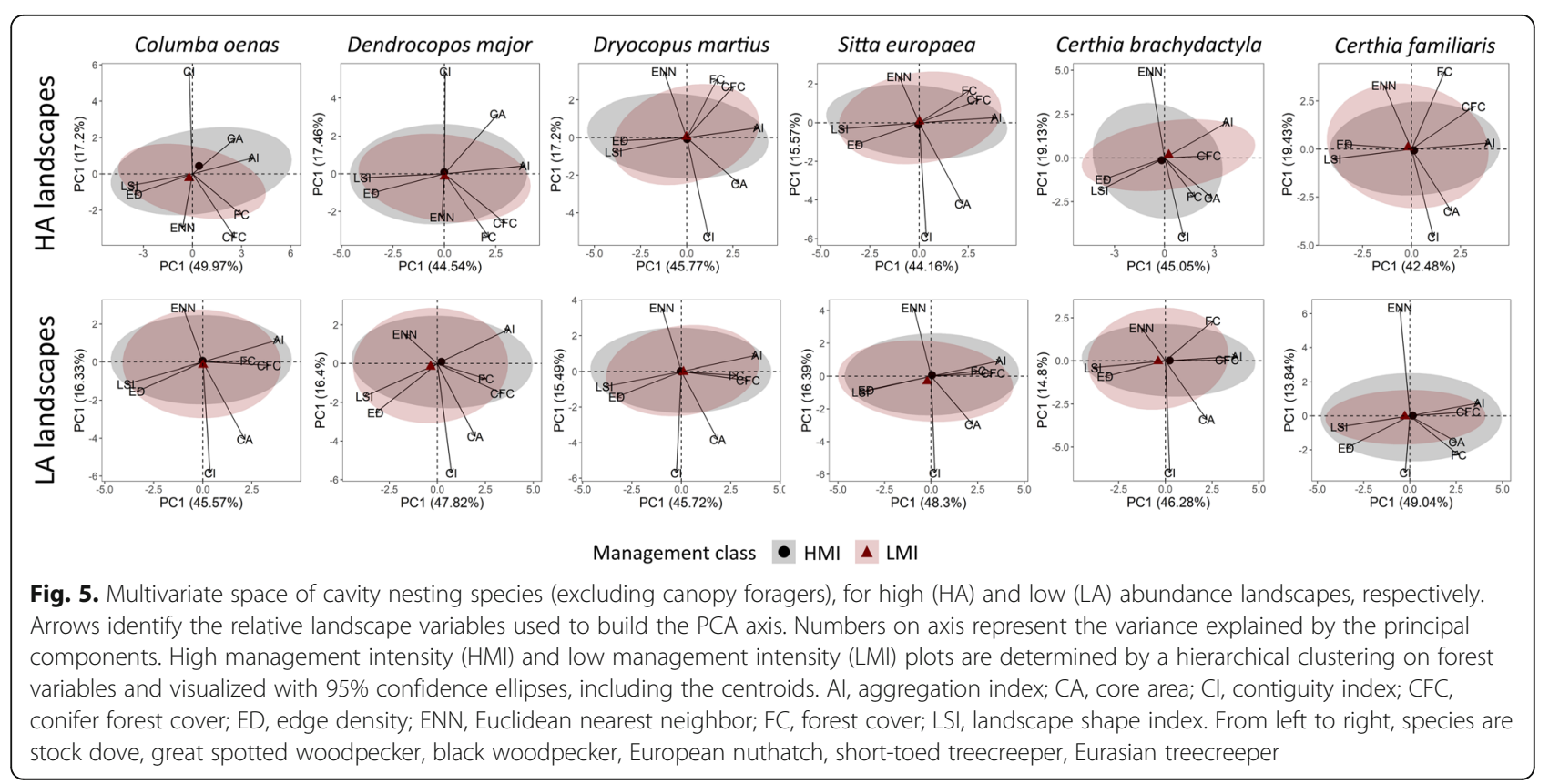



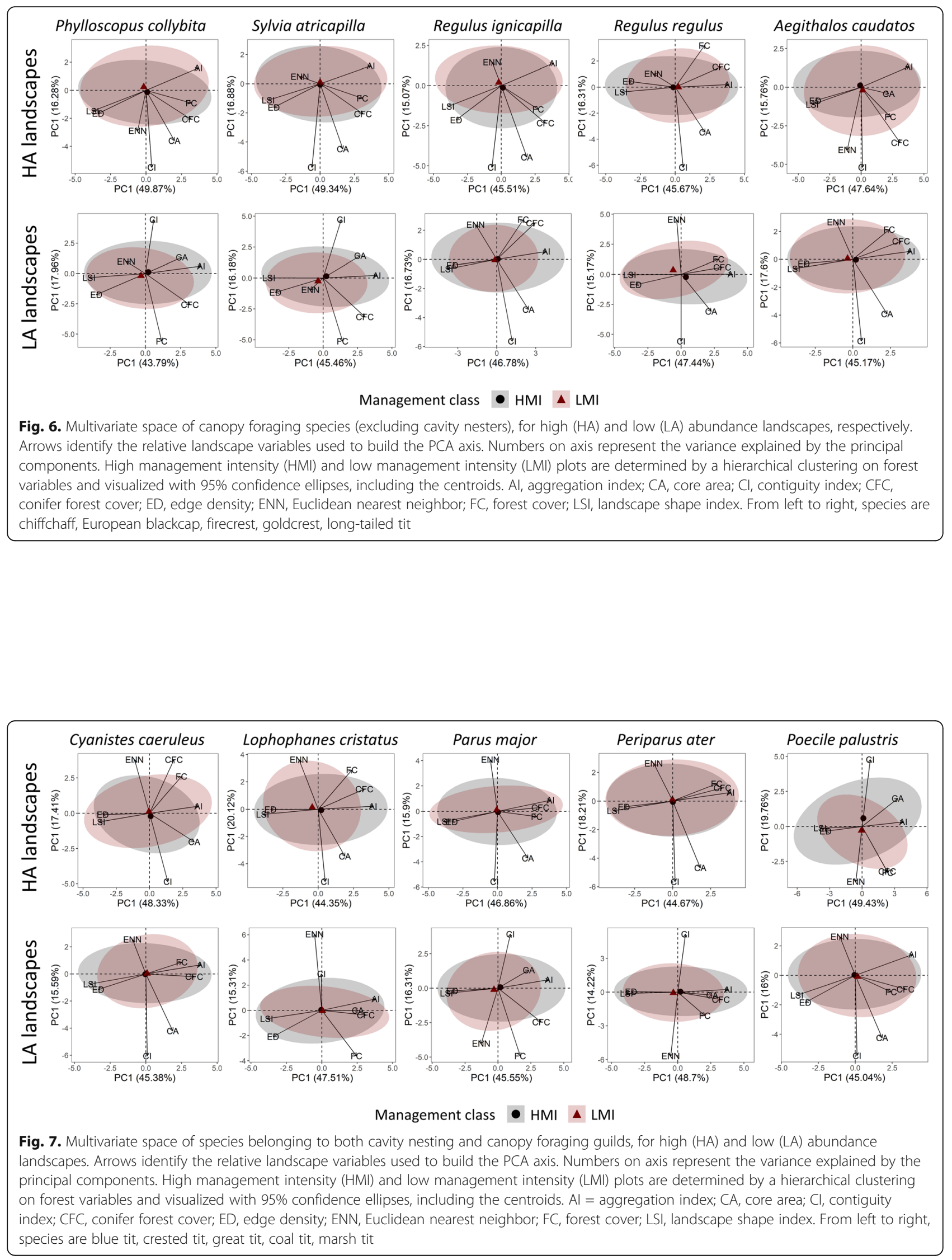
causation, it showed that, apparently, species associations can influence the local abundance of species, in addition to their environment-related baseline occurrence [11]. Our approach could evaluate only unidirectional effects between species pairs. Hence, we could not test all possible association effects, which may be reciprocal in some instances [40]. Another limitation of our model is that it did not evaluate potential interaction effects among species included as covariates. This should be addressed in future studies. We, also, did not include potential predators affecting the targeted species, another density-dependent process that may strongly affect habitat selection $[9,60]$. However, many species within the guilds studied are similar in size and life history and have mutualistic anti-predatory relationships [61].

As an example of how birds' habitat preferences were modulated by co-occurrences, we discuss the Eurasian treecreeper. According to our results concerning only forest variables, we would predict lower abundances at sites with high management intensity. However, the positive association between the crested tit and the Eurasian treecreeper predicts the latter to still persist in higher abundances at intensively managed sites. The mechanism behind the observation that increasing numbers of crested tits are associated with an increasing abundance of the Eurasian treecreeper is likely rooted in the network of relationships within the entire bird assemblage. One possible explanation could be that crested tit and treecreeper neither compete for food nor nest sites but may help each other to avoid predation and thereby elevate survival by participation in mixedspecies flock in winter. However, we did not directly observe that, but rather interpreted statistical associations as direct or indirect influence of a species on another one, causing the abundance of the species to change according to density-dependent processes, e.g., competition over resources [62]. Moreover, competitor species density can also cue other species about habitat quality and indirectly drive their local habitat selection [63].

Most of the species association effects were less important than forest variable effects, indicating that the primary determinant of species abundance remains the habitat structure. However, habitat structure cannot fully explain the processes of habitat selection and community assembly, without considering it alongside with other processes, such as competition or predation [1, 60]. Compelling evidence shows that it is not possible to separate the effect of environmental filtering from that of biotic interactions in traditional study settings [2]. Indeed, we observed that the relative abundances of cooccurring species are related to each other and, together with the environment, modulate the response of species to environmental gradients (environmental filtering). This raises the question whether interspecific associations play a similarly important role within forest bird guilds other than those investigated, whenever the set of resources they use is limited by forest management.

The effect of species associations sheds new light on the effect of forest structure on the targeted bird species. Conifer share at the plot scale influenced abundances of species mainly in a negative way, agreeing with other studies from the same [64] and other regions [65]. The effects of basal area and ForMI were mainly negative among species, despite different degrees of habitat specialization among species and the fact that management intensity is only moderately related to forest structure in our plots [66]. Still, specialized species responded negatively to management intensity, which is common among cavity nesters [43, 44]. Instead, the occurrence rates of forest generalist species, such as the great tit, are often associated with increasing management intensity [67]. Nonetheless, we observed a negative response to management intensity also for this species. The great tit is often found in coexistence with other members of the family Paridae, which may indicate mutualistic relationships [68, 69]. This coexistence is based on different types of resource partitioning leading to unique combinations of niche characteristics $[47,62]$. In particular, positive interactions among co-occurring species can be relevant in suboptimal habitats, where some species may facilitate the habitat use of others [70]. This becomes particularly evident outside the breeding season, when mixed-species flocking within the same foraging guild can improve the protection against predators and feeding efficiency [71]. Hence, we stress that positive responses to high management intensity may depend also on the identity of co-occurring species.

\section{Management intensity modifies the habitat preferences according to the landscape context}

Birds can exhibit larger territory areas, lower occupancy rates, and lower abundances in suboptimal habitats [7275]. In landscapes characterized by low abundances of forest birds (LA landscapes in our study), species may simply be forced to exploit a broader range of environmental conditions. Our analysis showed that some species (e.g., Eurasian treecreeper) occurred in high management intensity (HMI) plots across a wider set of environmental conditions (at the landscape scale), especially in suboptimal landscapes (i.e., with lower abundances). Previous studies related higher occurrence rates with more generalist habits in birds [25, 76]. Hence, populations of the same species could also increase their occurrence rate, by broadening their habitat preferences. Another study focusing on boreal forest birds provided findings similar to ours, indicating that the local habitat structure is a more important driver of niche breadth rather than landscape structure [19]. Species with and 
without interspecific associations showed similar abundance patterns across all landscapes, and the responses to environmental predictors among species were consistent with each other. Therefore, we can provide support to the statement that management intensity can modify the habitat structural preferences of forest birds, with the remark that this is more evident in suboptimal landscapes. Low abundances may be a result of habitat fragmentation, suboptimal habitat structure, disturbance, or other factors [77]. In this study, low abundances were found in landscapes characterized by smaller forest patch size and less forest cover. In fact, the landscape context may act as precondition for a species to utilize different environments [78, 79]. Moreover, studies focusing only on foraging guilds and including old-growth forests (not represented in our study) associated wider niche breadths with more pristine forests $[80,81]$. This is partly in accordance with our results in HA landscapes and LMI plots for Eurasian treecreeper, chiffchaff, and long-tailed tit. This showcases a great difficulty in optimizing conservation interventions for the widest possible array of species in forest management strategies targeting the conservation of forest bird species [82]. This is especially true for cavity nesters, the guild dominated by resident species with many of them being in jeopardy in managed forests in Europe [83-85]. It has been demonstrated that forest management may, through reducing niche diversity, largely affect the ability of closely related species and competing species to coexist [60].

\section{Conclusions}

Interspecific associations can result in striking differences in habitat selection for bird species with overlapping habitat preferences $[49,86]$. This highlights the plasticity of birds in their habitat use, and in their ability to exploit different habitat conditions. We showed that within the forest bird assemblage, species can display different habitat preferences according to the presence and abundance of co-occurring and associated species. This study suggests that interspecific associations result in higher abundances of some bird species in more intensively managed forests, which may be a consequence of factors beyond the local habitat structure. Hence, to design management actions based exclusively on species-habitat relationships may not necessarily deliver the best possible results, and managers should be aware of potential effects of interspecific associations. At the same time, in suboptimal landscapes species are forced to exploit a broader range of environmental conditions in intensively managed forests, which may hamper the effectiveness of conservation-oriented management wherever landscape-scale factors are not considered.

\section{Methods}

\section{Study area}

The study was performed in 127 1-ha plots located in the forest landscape of the Black Forest, southwestern Germany, (latitude $47.6^{\circ}-48.3^{\circ} \mathrm{N}$, longitude $7.7^{\circ}-8.6^{\circ} \mathrm{E}$; WGS 84). Plots were selected in the framework of the ConFoBi Research Training Group ([87]; confobi.unifreiburg.de). Selection focused on stands with tree age over 60 years and located at least $1 \mathrm{~km}$ from each other. A stratified-random selection was then applied along two environmental gradients, representing the local habitat structure (number of standing dead trees per plot) and the landscape context (forest cover in the 25 $\mathrm{km}^{2}$ surrounding the plot), respectively. The forest management practiced in the study area consists of single tree selection under close-to-nature forest management leading to continuous cover forests [88, 89]. The plots ranged, in terms of elevation, between 443 and $1334 \mathrm{~m}$ a.s.l., and represented a typical temperate mixed mountain forest, dominated by Norway spruce (Picea abies) (42.8\%), silver fir (Abies alba) (18.5\%), and European beech (Fagus sylvatica) (15.3\%). Due to the forest management history of the study area, conifer and mixedconifer forests occur throughout the above elevation range, also outside of their natural altitudinal distribution.

\section{Environmental predictors}

The environmental descriptors included in the analysis were collected at the plot scale ( $1 \mathrm{ha})$, containing forest structure data, and at the landscape scale (up to $5 \mathrm{~km}^{2}$ ), including several landscape configuration metrics and forest cover. The spatial scale of each predictor reflected both the overall study design [87] and the extents at which bird-related ecological processes are usually investigated [90-93].

\section{Forest variables}

The forest structure of the plots was described in terms of tree basal area, share of conifers, richness and abundance of TreMs [94], an index of forest management intensity [95], tree species composition and deadwood volume. An inventory used to describe forest structure comprised species identity and diameter at breast height (DBH) of all living trees (with DBH $>7 \mathrm{~cm}$ ), from which basal area and the share of conifers were derived. In addition, the DBH of all snags (with DBH $>7 \mathrm{~cm}$ and height $>1.3 \mathrm{~m}$ ) on the plots was measured. Lying deadwood data was collected using the line intersect method, consisting in walking a V-transect from the north-east corner to the center of the southern plot border to the north-west corner of each plot and counting all deadwood intersecting the transect [96]. The abundance and richness of TreMs was retrieved from previous research 
in the same plots [94]. TreMs are considered to be "a distinct, well delineated structure occurring on living or standing dead trees, that constitutes a particular and essential substrate or life site for species or species communities during at least a part of their life cycle to develop, feed on, using as shelter or to breed" [57] and have shown correlations to the richness and abundance of forest-dwelling vertebrates and (saproxylic) insects [5, 6 , 97]. TreMs are usually grouped into seven forms, including cavities, tree injuries and exposed wood, crown deadwood, excrescences, fruiting bodies of saproxylic fungi and slime molds, epiphytic, epixylic and parasitic structures, and fresh exudates such as sap run and heavy resinosis [98]. The forest management intensity index (ForMI), calculated from forest variables, measured three different management aspects [95]: (a) the proportion of harvested tree volume compared to the maximum volume, (b) the proportion of tree species not belonging to the natural species composition, and (c) the ratio of artificial (showing signs of cutting) vs. natural deadwood. The index spans values $0-3$, where 0 would indicate a forest not managed for timber production and 3 an intensively managed production forest. In addition, the average altitude of each plot was provided from a digital terrain model with spatial resolution of $0.5 \mathrm{~m}$ (State Office for Geoinformation and Land Development BadenWürttemberg, Germany).

\section{Landscape variables}

The landscape-scale predictors included the forest cover-based metrics describing the fragmentation of the forest surrounding the plots. Forest cover was derived from the land cover map provided by the State Office for Geoinformation and Land Development of Baden-Württemberg, Germany (Geobasdata $\odot$, www. lgl-bw.de, ref. no: 2851.9-1/19). Forest cover was assessed in the neighboring five $\mathrm{km}^{2}$ circular area, separately for conifer and total forest. The landscape metrics were computed on the same land cover map, using only areas classified as forest for the computation (i.e., binary map), and employed the software FRAGSTATS [99]. We considered six metrics commonly employed to describe fragmentation and patchiness of the landscape: the aggregation index, the contiguity area index, the core area index, the edge density, the Euclidean nearest neighbor, and the landscape shape index. These metrics were selected because either evidence or experts suggest they have an effect on the numerical response of birds [90-93].

\section{Bird sampling}

Birds were sampled using standardized point counts with limited distance of $50 \mathrm{~m}$, each conducted from the plot center. Point counts were repeated up to three times/year during the period March-June in years 2017-2019 (i.e., encompassing most of the breeding season), starting half an hour after sunrise with the latest sample collected at 12:00 CET. Each survey at each plot lasted $20 \mathrm{~min}$, during which bird individuals were recorded repeatedly every $5 \mathrm{~min}$, in order to reach a reasonable sample coverage [100, 101].

Each bird species was classified as cavity nester, insectivorous canopy forager, or both according to standard references $[28,102,103]$. We adopted the rule of thumb for skewed distribution and excluded species recorded less than 30 times in the entire study from the analysis, to trade-off between number of species and robustness of the analysis. To estimate the effect of the cooccurrence of a given species on a potentially associated one, we established linkages between species, i.e., assumed that the abundance of a species is correlated to the abundance of another one. To inform the direction of the linkage, i.e., whether species $\mathrm{A}$ is presumably affecting species $\mathrm{B}$ or the opposite, we relied on the existing literature (see Additional file 1, Table S1) [28-30, 34, $35,37-46,48,49,69,102,104-113]$.

\section{Abundance estimates}

To account for co-occurrence effects on species responses to habitat structures, bird abundance was estimated using community N-mixture models $[114,115]$. Such models allow for estimating the abundance of species belonging to an assemblage as a function of environmental predictors, considering the detectability error by employing count data from repeated surveys. Our models incorporated the density-dependent effect of cooccurring and potentially associated species (Additional file 2). Species were paired according to their relationship (as described in Additional file S1), and assumptions about the direction of the relationship were not made. That is, after establishing from the literature that the species A is presumably affecting species B, and hence their abundances are correlated, we did not assume this correlation to be positive or negative, but only density-dependent. We restricted our analysis by focusing only on the cavity nester and canopy forager species found in our study area, which potentially compete over resources. Hence, if a relationship was present, the abundance of species A was considered a covariate of the response variable, i.e., the abundance of the species B, similarly to other research on species co-occurrences [116]. Species abundance was modeled as a Poisson process, while the detectability was modeled as a binomial distribution, dependent on the abundance process and moderated by the date and time of each survey, to model individual heterogeneity in detectability. The forest variables included in the species abundance model had a variance inflation factor $\leq 3$, indicating that 
multicollinearity was not an issue. All predictors were scaled prior to analysis. The full model was built in JAGS programming language and fitted by applying Bayesian inference. We used uninformative priors and ran three MCMC chains of 400,000 iterations, discarding the first 10,000 and thinning by 90 . We considered reliable model parameter estimates those drawn from a posterior distribution where the proportion with the same sign as the mean was $f \geq 0.9$. If this was not the case, the model parameter was discarded from the analysis and the model ran again. We considered that chains reached convergence when the Gelman-Rubin statistic (r-hat) was $\leq 1.1$ for all parameters [117]. All analyses were conducted in the $\mathrm{R}$ statistical environment. The community model was built with the package "jagsUI" [118]. Model posterior means including associations were compared against the means of the model without association using $95 \%$ confidence ellipses.

\section{Habitat characterization}

To account for the effect of management intensity on species' responses to habitat at local scale, the forest structure of each plot was characterized by performing hierarchical clustering of the forest variables, aimed at grouping them in two clusters of high management intensity (HMI) and low management intensity (LMI) plots. Each plot was assigned to a category of management intensity using the $\mathrm{K}$-means clustering method on the forest variables. At the landscape scale, instead, we characterized the landscape structure by building two gradients using the first two components of a principal component analysis (PCA) on the correlation matrix of landscape variables. Considering that species perceive the landscape according to their life histories, we performed PCAs on the guilds and on each species. More or less fragmented landscape configurations can result in very different bird abundances $[72,119]$. Therefore, we considered optimal landscapes as those where the estimated abundance at plot level was higher than the mean abundance observed across the study area ( 0 after scaling). In this way, we characterized both the landscape with high (HA) and low (LA) abundances, as proxies for optimal and suboptimal-to-unsuitable landscapes, and each included both HMI and LMI plots. We performed a permutational Multivariate ANalysis Of VAriance (perMANOVA), to test whether each landscape variable associated to each plot differed among management intensity classes to further confirm that landscape structure was independent from forest structure. Then, we compared the habitat structure for HMI and LMI plots along the landscape gradients in LA and HA landscapes. We calculated the abundance of each guild by summing up the respective species' estimated abundances and scaling them. The habitat structure was visualized by plotting the 95\% confidence ellipses of abundance estimates and visually comparing the respective position and width. The R package 'vegan' was employed for the analysis [120].

\section{Supplementary Information}

The online version contains supplementary material available at https://doi. org/10.1186/s12915-021-01136-8.

Additional file 1 Species classification in the cavity nester and canopy forager guilds. Based on the reference, we established 77 potential associations. Figure S1. Potential relationship between species identified or suggested in the literature. Table S1. Species associations derived from the literature, experts' comments or inferred from body size and closely-related species

Additional file 2. Multi-species abundance model incorporating the species association process.

\begin{abstract}
Acknowledgements
We are very thankful to J. Wildraut, C. Pacioni, and M. von VequelWesternach for the support provided in the field collection of bird data, to C. Pacioni for the help in managing the data, to F. Hauck and J. Grossmann for the support provided in the TreM and ForMl data collection, and to J. Dilger, D. Saladin, and J. Memmert for conducting the forest inventory.
\end{abstract}

\section{Authors' contributions}

$\mathrm{MB}$ conceptualized the research questions; IS conceptualized the overarching study design; MB, TA, and GM collected the data; MB, TA, and JMCP prepared a first draft of the manuscript; and GM and IS critically contributed to the writing. The authors read and approved the final manuscript.

\section{Funding}

Funding for this research was provided by the German Research Foundation (DFG), under the ConFoBi Research Training Group "Conservation of Forest Biodiversity in Multiple-Use Landscapes of Central Europe" (GRK 2123). Open Access funding enabled and organized by Projekt DEAL.

\section{Availability of data and materials}

The dataset supporting the conclusions of this article is available in the ConFoBi database repository, http://confobi-db.vm.uni-freiburg.de/ geonetwork/srv/ger/catalog.search\#/home

\section{Declarations}

Ethics approval and consent to participate

Not applicable.

Consent for publication

Not applicable.

Competing interests

The authors declare that they have no competing interests.

\section{Author details}

${ }^{1}$ Chair of Wildlife Ecology and Management, University of Freiburg, Tennenbacher Str. 4, 79106 Freiburg, Germany. ${ }^{2}$ Swiss Federal Research Institute WSL, Zürcherstrasse 111, 8903 Birmensdorf, Switzerland. ${ }^{3}$ Swiss Ornithological Institute, Seerose 1, 6204 Sempach, Switzerland. ${ }^{4}$ Chair of Silviculture, University of Freiburg, Tennenbacher Str. 4, 79106 Freiburg, Germany. ${ }^{5}$ Grimsö Wildlife Research Station, Department of Ecology, Swedish University of Agricultural Sciences SLU, SE-730 91 Riddarhyttan, Sweden. ${ }^{6}$ School for Forest Management, Swedish University of Agricultural Sciences SLU, SE-739 21 Skinnskatteberg, Sweden. 
Received: 29 December 2020 Accepted: 28 August 2021

\section{Published online: 23 September 2021}

\section{References}

1. Cadotte MW, Tucker CM. Should environmental filtering be abandoned? Trends Ecol Evol. 2017;32(6):429-37. https://doi.org/10.1016/j.tree.2017.03.004.

2. Kraft NJB, Adler PB, Godoy O, James EC, Fuller S, Levine JM. Community assembly, coexistence and the environmental filtering metaphor. Funct Ecol. 2015;29(5):592-9. https://doi.org/10.1111/1365-2435.12345.

3. Plue J, Van Gils B, De Schrijver A, Peppler-Lisbach C, Verheyen K, Hermy M. Forest herb layer response to long-term light deficit along a forest developmental series. Acta Oecologica. 2013;53:63-72. https://doi.org/10.101 6/j.actao.2013.09.005

4. Frouz J, Livečková M, Albrechtová J, Chroňáková A, Cajthaml T, Pižl V, et al. Is the effect of trees on soil properties mediated by soil fauna? A case study from post-mining sites. For Ecol Manage. 2013;309:87-95. https://doi.org/1 0.1016/j.foreco.2013.02.013

5. Basile M, Asbeck T, Jonker M, Knuff AK, Bauhus J, Braunisch V, et al. What do tree-related microhabitats tell us about the abundance of forest-dwelling bats, birds, and insects? J Environ Manage. 2020;264:110401. https://doi. org/10.1016/j.jenvman.2020.110401.

6. Paillet $Y$, Archaux F, du Puy S, Bouget C, Boulanger V, Debaive N, et al. The indicator side of tree microhabitats: a multi-taxon approach based on bats, birds and saproxylic beetles. J Appl Ecol. 2018;55(5):2147-59. https://doi. org/10.1111/1365-2664.13181.

7. Iwińska K, Boratyński JS, Trivedi A, Borowski Z. Daily roost utilization by edible dormouse in a managed pine-dominated forest. For Ecol Manage. 2020;468:118172. https://doi.org/10.1016/j.foreco.2020.118172.

8. Grinde AR, Niemi GJ. A synthesis of species interactions, metacommunities, and the conservation of avian diversity in hemiboreal and boreal forests. J Avian Biol. 2016:47(5):706-18. https://doi.org/10.1111/jav.01036.

9. Chase JM, Abrams PA, Grover JP, Diehl S, Chesson P, Holt RD, et al. The interaction between predation and competition: a review and synthesis. Ecol Lett. 2002;5(2):302-15. https://doi.org/10.1046/j.14610248.2002.00315.x.

10. Bruno JF, Stachowicz JJ, Bertness MD. Inclusion of facilitation into ecological theory. Trends Ecol Evol. 2003;18(3):119-25. https://doi.org/10.1016/S01695347(02)00045-9.

11. Dormann CF, Bobrowski M, Dehling DM, Harris DJ, Hartig F, Lischke $H$, et al. Biotic interactions in species distribution modelling: 10 questions to guide interpretation and avoid false conclusions. Glob Ecol Biogeogr. 2018;27(9): 1004-16. https://doi.org/10.1111/geb.12759.

12. Blanchet FG, Cazelles K, Gravel D. Co-occurrence is not evidence of ecological interactions. Ecol Lett. 2020;23(7):1050-63. https://doi.org/1 $0.1111 /$ ele.13525.

13. Heikkinen RK, Luoto M, Virkkala R, Pearson RG, Körber JH. Biotic interactions improve prediction of boreal bird distributions at macroscales. Glob Ecol Biogeogr. 2007;16(6):754-63. https://doi.org/10.1111/j.14 66-8238.2007.00345.x

14. Costa A, Salvidio S, Posillico M, Matteucci G, De Cinti B, Romano A. Generalisation within specialization: inter-individual diet variation in the only specialized salamander in the world. Sci Rep. 2015;5:13260. https://doi.org/1 0.1038/srep13260.

15. Rieman BE, Peterson JT, Myers DL. Have brook trout (Salvelinus fontinalis) displaced bull trout (Salvelinus confluentus) along longitudinal gradients in central Idaho streams? Can J Fish Aquat Sci. 2006;63(1):63-78. https://doi. org/10.1139/f05-206.

16. Hutchinson GE. Concluding remarks. Cold Spring Harb Symp Quant Biol. 1957:22(0):415-27. https://doi.org/10.1101/SOB.1957.022.01.039.

17. Holt RD. Bringing the Hutchinsonian niche into the 21st century: ecological and evolutionary perspectives. Proc Natl Acad Sci. 2009;106(Supplement_2): 19659-65. https://doi.org/10.1073/pnas.0905137106.

18. Scheele BC, Foster CN, Banks SC, Lindenmayer DB. Niche contractions in declining species: mechanisms and consequences. Trends Ecol Evol. 2017; 32(5):346-55. https://doi.org/10.1016/j.tree.2017.02.013.

19. Mahon CL, Holloway G, Sólymos P, Cumming SG, Bayne EM, Schmiegelow FKA, et al. Community structure and niche characteristics of upland and lowland western boreal birds at multiple spatial scales. For Ecol Manage. 2016;361:99-116. https://doi.org/10.1016/j.foreco.2015.11.007.

20. Basile $M$, Balestrieri R, de Groot M, Flajšman K, Posillico M. Conservation of birds as a function of forestry. Ital J Agron. 2016;11:42-8.
21. Machar I, Schlossarek M, Pechanec V, Uradnicek L, Praus L, Sivacıoğlu A, et al. Retention forestry supports bird diversity in managed, temperate hardwood floodplain forests. Forests. 2019;10(4):300. https://doi.org/10.3390/ f10040300.

22. Vélová L, Véle A, Horák J. Land use diversity and prey availability structure the bird communities in Norway spruce plantation forests. For Ecol Manage. 2021;480:118657. https://doi.org/10.1016/j.foreco.2020.118657.

23. Lešo $P$, Kropil R, Kajtoch $\measuredangle$. Effects of forest management on bird assemblages in oak-dominated stands of the Western Carpathians - refuges for rare species. For Ecol Manage. 2019:453:117620. https://doi.org/10.1016/j. foreco.2019.117620.

24. Torrenta R, Lacoste F, Villard M-A. Loss and fragmentation of mature woodland reduce the habitat niche breadth of forest birds. Landsc Ecol. 2018;33(11):1865-79. https://doi.org/10.1007/s10980-018-0718-9.

25. Kellner KF, Duchamp JE, Swihart RK. Niche breadth and vertebrate sensitivity to habitat modification: signals from multiple taxa across replicated landscapes. Biodivers Conserv. 2019:1-21. https://doi.org/10.1007/s10531-01 9-01785-W.

26. Villard M-A, Haché $\mathrm{S}$. Conifer plantations consistently act as barriers to movement in a deciduous forest songbird: a translocation experiment. Biol Conserv. 2012;155:33-7. https://doi.org/10.1016/J.BIOCON.2012.06.007.

27. Basile M, Mikusiński G, Storch I. Bird guilds show different responses to tree retention levels: a meta-analysis. Glob Ecol Conserv. 2019;18:e0615. https:// doi.org/10.1016/j.gecco.2019.e00615.

28. Newton I. The role of nest sites in limiting the numbers of hole-nesting birds: a review. Biol Conserv. 1994;70(3):265-76. https://doi.org/10.1016/ 0006-3207(94)90172-4.

29. Pasinelli G. Nest site selection in middle and great spotted woodpeckers Dendrocopos medius \& D. major: implications for forest management and conservation. Biodivers Conserv. 2007;16(4):1283-98. https://doi.org/10.1007/ s10531-007-9162-x

30. Balestrieri R, Basile M, Romano S, Ferraro S, Izzo M, Posillico M, et al. Breeding performance of blue tits Cyanistes caeruleus can be predicted from time since last logging in Mediterranean mixed oak forest. Avocetta. 2018;42:67-73.

31. Cockle KL, Martin K, Drever MC. Supply of tree-holes limits nest density of cavity-nesting birds in primary and logged subtropical Atlantic forest. Biol Conserv. 2010;143(11):2851-7. https://doi.org/10.1016/j.biocon.2010.08.002.

32. Robles $\mathrm{H}$, Ciudad C, Matthysen E. Tree-cavity occurrence, cavity occupation and reproductive performance of secondary cavity-nesting birds in oak forests: the role of traditional management practices. For Ecol Manage. 2011;261(8):1428-35. https://doi.org/10.1016/j.foreco.2011.01.029.

33. Wesołowski T, Martin K. Tree holes and hole-nesting birds in European and North American forests. In: Mikusiński G, Roberge J-M, Fuller RJ, editors. Ecology and conservation of forest birds. Cambridge: Cambridge University Press; 2018. p. 79-133. https://doi.org/10.1017/9781139680363.006.

34. Wesołowski T. Lessons from long-term hole-nester studies in a primeval temperate forest. J Ornithol. 2007;148(SUPLL. 2):S395-405.

35. Spiering DJ, Knight RL. Snag density and use by cavity-nesting birds in managed stands of the Black Hills National Forest. For Ecol Manage. 2005; 214(1-3):40-52. https://doi.org/10.1016/j.foreco.2005.03.054.

36. Basile M, Asbeck T, Pacioni C, Mikusiński G, Storch I. Woodpecker cavity establishment in managed forests: relative rather than absolute tree size matters. Wildlife Biol. 2020;2020(1). https://doi.org/10.2981/ wlb.00564.

37. Remm J, Lõhmus A, Remm K. Tree cavities in riverine forests: what determines their occurrence and use by hole-nesting passerines? For Ecol Manage. 2006;221(1-3):267-77. https://doi.org/10.1016/j.foreco.2005.10.015.

38. Mahon CL, Steventon JD, Martin K. Cavity and bark nesting bird response to partial cutting in Northern conifer forests. For Ecol Manage. 2008;256(12): 2145-53. https://doi.org/10.1016/j.foreco.2008.08.005.

39. Kosiński Z, Pluta M, Ulanowska A, Walczak Ł, Winiecki A, Mateusz Z. Do increases in the availability of standing dead trees affect the abundance, nest-site use, and niche partitioning of great spotted and middle spotted woodpeckers in riverine forests? Biodivers Conserv. 2018;27(1):123-45. https://doi.org/10.1007/s10531-017-1425-6.

40. Nilsson SG. The evolution of nest-site selection among hole-nesting birds: the importance of nest predation and competition. Ornis Scand. 1984;15(3): 167-75. https://doi.org/10.2307/3675958.

41. Parejo D, Avilés JM. Predation risk determines breeding territory choice in a Mediterranean cavity-nesting bird community. Oecologia. 2011;165(1):18591. https://doi.org/10.1007/s00442-010-1723-0. 
42. Kobayashi F, Toyama M, Koizumi I. Potential resource competition between an invasive mammal and native birds: overlap in tree cavity preferences of feral raccoons and Ural owls. Biol Invasions. 2014;16(7):1453-64. https://doi. org/10.1007/s10530-013-0583-z.

43. Balestrieri R, Basile M, Posillico M, Altea T, De Cinti B, Matteucci G. A guildbased approach to assessing the influence of beech forest structure on bird communities. For Ecol Manage. 2015;356:216-23. https://doi.org/10.1016/j. foreco.2015.07.011

44. Czeszczewik D, Zub K, Stanski T, Sahel M, Kapusta A, Walankiewicz W. Effects of forest management on bird assemblages in the Bialowieza Forest, Poland. iForest - Biogeosciences For. 2015;8(3):377-85. https://doi.org/10.3 832/ifor1212-007.

45. Ameztegui A, Gil-Tena A, Faus J, Piqué M, Brotons L, Camprodon J. Bird community response in mountain pine forests of the Pyrenees managed under a shelterwood system. For Ecol Manage. 2017;407:95-105. https://doi. org/10.1016/j.foreco.2017.09.002.

46. Verner J. The guild concept applied to management of bird populations. Environ Manage. 1984;8(1):1-13. https://doi.org/10.1007/BF01867868.

47. Díaz M, Illera JC, Atienza JC. Food resource matching by foraging tits Parus spp. during spring-summer in a Mediterranean mixed forest; evidence for an ideal free distribution. Ibis (Lond 1859). 1998;140:654-60.

48. Dhondt AA. Interspecific competition between great and blue tit. Nature. 1977;268(5620):521-3. https://doi.org/10.1038/268521a0.

49. Alatalo RV. Multidimensional foraging niche organization of foliage-gleaning birds in Northern Finland. Ornis Scand. 1982;13(1):56. https://doi.org/10.23 07/3675974.

50. Andersson J, Domingo Gómez E, Michon S, Roberge JM. Tree cavity densities and characteristics in managed and unmanaged Swedish boreal forest. Scand J For Res. 2018;33(3):233-44. https://doi.org/10.1080/0282 7581.2017.1360389.

51. Müller J, Hothorn T, Pretzsch H. Long-term effects of logging intensity on structures, birds, saproxylic beetles and wood-inhabiting fungi in stands of European beech Fagus sylvatica L. For Ecol Manage. 2007;242(2-3):297-305. https://doi.org/10.1016/j.foreco.2007.01.046.

52. LaManna JA, Martin TE. Logging impacts on avian species richness and composition differ across latitudes and foraging and breeding habitat preferences. Biol Rev. 2017;92(3):1657-74. https://doi.org/10.1111/brv.12300.

53. Asbeck T, Sabatini F, Augustynczik ALD, Basile M, Helbach J, Jonker M, et al. Biodiversity response to forest management intensity, carbon stocks and net primary production in temperate montane forests. Sci Rep. 2021;11(1): 1625. https://doi.org/10.1038/s41598-020-80499-4.

54. Suhonen J, Halonen M, Mappes T. Predation risk and the organization of the Parus guild. Oikos. 1993;66(1):94-100. https://doi.org/10.2307/3545200.

55. Brockerhoff EG, Jactel H, Parrotta JA, Quine CP, Sayer J. Plantation forests and biodiversity: oxymoron or opportunity? Biodivers Conserv. 2008;17(5): 925-51. https://doi.org/10.1007/s10531-008-9380-x

56. Waltert M, Bobo KS, Sainge NM, Fermon H, Mühlenberg M. From forest to farmland: habitat effects on afrotropical forest bird diversity. Ecol Appl. 2005; 15(4):1351-66. https://doi.org/10.1890/04-1002.

57. Larrieu L, Paillet $Y$, Winter S, Bütler R, Kraus D, Krumm F, et al. Tree related microhabitats in temperate and Mediterranean European forests: a hierarchical typology for inventory standardization. Ecol Indic. 2018;84:194207. https://doi.org/10.1016/j.ecolind.2017.08.051.

58. Chamberlain SA, Bronstein JL, Rudgers JA. How context dependent are species interactions? Ecol Lett. 2014;17(7):881-90. https://doi.org/10.1111/ ele.12279.

59. Tylianakis JM, Didham RK, Bascompte J, Wardle DA. Global change and species interactions in terrestrial ecosystems. Ecol Lett. 2008;11(12):1351-63. https://doi.org/10.1111/j.1461-0248.2008.01250.x.

60. Eggers S, Low M. Differential demographic responses of sympatric Parids to vegetation management in boreal forest. For Ecol Manage. 2014;319:16975. https://doi.org/10.1016/j.foreco.2014.02.019.

61. Carrascal LM, Moreno E. Proximal costs and benefits of heterospecific social foraging in the great tit, Parus major. Can J Zool. 1992;70(10):1947-52. https://doi.org/10.1139/z92-264.

62. Atiénzar F, Belda EJ, Barba E. Coexistence of mediterranean tits: a multidimensional approach. Ecoscience. 2013;20(1):40-7. https://doi.org/10.2 980/20-1-3516.

63. Forsman JT, Hjernquist MB, Taipale J, Gustafsson L. Competitor density cues for habitat quality facilitating habitat selection and investment decisions. Behav Ecol. 2008;19(3):539-45. https://doi.org/10.1093/beheco/arn005.
64. Augustynczik ALD, Asbeck T, Basile M, Bauhus J, Storch I, Mikusiński G, et al. Diversification of forest management regimes secures tree microhabitats and bird abundance under climate change. Sci Total Environ. 2019;650: 2717-30. https://doi.org/10.1016/j.scitotenv.2018.09.366.

65. Roberge JM, Angelstam P. Indicator species among resident forest birds - a cross-regional evaluation in northern Europe. Biol Conserv. 2006;130(1):13447. https://doi.org/10.1016/j.biocon.2005.12.008.

66. Asbeck T, Frey J. Weak relationships of continuous forest management intensity and remotely sensed stand structural complexity in temperate mountain forests. Eur J For Res. 2021;140(3):721-31. https://doi.org/10.1007/ s10342-021-01361-4

67. Schulze ED, Craven D, Durso AM, Reif J, Guderle M, Kroiher F, et al. Positive association between forest management, environmental change, and forest bird abundance. For Ecosyst. 2019;6(1):3. https://doi.org/10.1186/s40663-0190160-8.

68. Robles H, Ciudad C, Matthysen E. Responses to experimental reduction and increase of cavities by a secondary cavity-nesting bird community in cavityrich Pyrenean oak forests. For Ecol Manage. 2012;277:46-53. https://doi. org/10.1016/j.foreco.2012.04.017.

69. Alatalo RV, Eriksson D, Gustafsson L, Larsson K. Exploitation competition influences the use of foraging sites by tits: experimental evidence. Ecology. 1987;68(2):284-90. https://doi.org/10.2307/1939259.

70. Mammides C, Chen J, Goodale UM, Kotagama SW, Sidhu S, Goodale E. Does mixed-species flocking influence how birds respond to a gradient of landuse intensity? Proc R Soc B Biol Sci. 2015;282:20151118. https://doi.org/10.1 098/rspb.2015.1118

71. Mönkkönen M, Forsman JT, Helle P. Mixed-species foraging aggregations and heterospecific attraction in boreal bird communities. Oikos. 1996;77(1): 127. https://doi.org/10.2307/3545592.

72. Basile M, Valerio F, Balestrieri R, Posillico M, Bucci R, Altea T, et al. Patchiness of forest landscape can predict species distribution better than abundance: the case of a forest-dwelling passerine, the short-toed treecreeper, in central Italy. PeerJ. 2016;4:e2398. https://doi.org/10.7717/peerj.2398.

73. Brambilla M, Ficetola GF. Species distribution models as a tool to estimate reproductive parameters: a case study with a passerine bird species. J Anim Ecol. 2012:81(4):781-7. https://doi.org/10.1111/j.1365-2656.2012.01970.x.

74. VanDerWal J, Shoo LP, Johnson CN, Williams SE. Abundance and the environmental niche: environmental suitability estimated from niche models predicts the upper limit of local abundance. Am Nat. 2009;174(2): 282-91. https://doi.org/10.1086/600087.

75. Suorsa P, Huhta E, Jäntti A, Nikula A, Helle H, Kuitunen M, et al. Thresholds in selection of breeding habitat by the Eurasian treecreeper (Certhia familiaris). Biol Conserv. 2005;121(3):443-52. https://doi.org/10.1016/j. biocon.2004.05.014.

76. Swihart RK, Lusk JJ, Duchamp JE, Rizkalla CE, Moore JE. The roles of landscape context, niche breadth, and range boundaries in predicting species responses to habitat alteration. Divers Distrib. 2006;12(3):277-87. https://doi.org/10.1111/j.1366-9516.2006.00242.x.

77. Lelli C, Bruun HH, Chiarucci A, Donati D, Frascaroli F, Fritz Ö, et al. Biodiversity response to forest structure and management: comparing species richness, conservation relevant species and functional diversity as metrics in forest conservation. For Ecol Manage. 2019;432:707-17. https:// doi.org/10.1016/J.FORECO.2018.09.057.

78. Davies SJ, Hill MP, McGeoch MA, Clusella-Trullas S. Niche shift and resource supplementation facilitate an amphibian range expansion. Divers Distrib. 2019;25(1):154-65. https://doi.org/10.1111/ddi.12841.

79. Resasco J, Tuff KT, Cunningham SA, Melbourne BA, Hicks AL, Newsome SD, et al. Generalist predator's niche shifts reveal ecosystem changes in an experimentally fragmented landscape. Ecography (Cop). 2018;41:1209-19.

80. Adamík P, Korňan M, Vojtek J. The effect of habitat structure on guild patterns and the foraging strategies of insectivorous birds in forests. Biol Sect Zool. 2003;58:275-85.

81. Sasvári L, Moskat C. Species richness, bird density and niche shifts in Central-European man-made habitats. Ecol. 1988;7:121-46.

82. Lindbladh M, Hedwall P-O, Holmström E, Petersson L, Felton A. How generalist are these forest specialists? What Sweden's avian indicators indicate. Anim Conserv. 2020;23(6):762-73. https://doi.org/10.1111/acv.12 595.

83. Enoksson B, Angelstam P, Larsson K. Deciduous forest and resident birds: the problem of fragmentation within a coniferous forest landscape. Landsc Ecol. 1995;10(5):267-75. https://doi.org/10.1007/BF00128994. 
84. Imbeau $L$, Mönkkönen $M$, Desrochers $A$. Long-term effects of forestry on birds of the eastern Canadian boreal forests: a comparison with Fennoscandia. Conserv Biol. 2001;15(4):1151-62. https://doi.org/10.1046/j.1 523-1739.2001.0150041151.x.

85. Hagan JM, McKinley PS, Meehan AL, Grove SL. Diversity and abundance of landbirds in a northeastern industrial forest. J Wildl Manage. 1997;61(3):71835. https://doi.org/10.2307/3802179.

86. Reif J, Reifová R, Skoracka A, Kuczyński L. Competition-driven niche segregation on a landscape scale: evidence for escaping from syntopy towards allotopy in two coexisting sibling passerine species. J Anim Ecol. 2018;87(3):774-89. https://doi.org/10.1111/1365-2656.12808.

87. Storch I, Penner J, Asbeck T, Basile M, Bauhus J, Braunisch V, et al. Evaluating the effectiveness of retention forestry to enhance biodiversity in production forests of Central Europe using an interdisciplinary, multi-scale approach. Ecol Evol. 2020;2019:ece3.6003. https://doi.org/10.1002/ece3.6003.

88. Gustafsson L, Bauhus J, Asbeck T, Augustynczik ALD, Basile M, Frey J, et al. Retention as an integrated biodiversity conservation approach for continuous-cover forestry in Europe. Ambio. 2020;49(1):85-97. https://doi. org/10.1007/s13280-019-01190-1.

89. Bauhus J, Puettmannn KJ, Kühne C. Close-to-nature forest management in Europe: does it support complexity and adaptability of forest ecosystems? In: Managing forests as complex adaptive systems: building resilience to the challenge of global change. New York: Routledge/The Earthscan Forest Library; 2013. p. 187-213.

90. Hofmeister J, Hošek J, Brabec M, Kočvara R. Spatial distribution of bird communities in small forest fragments in central Europe in relation to distance to the forest edge, fragment size and type of forest. For Ecol Manage. 2017:401:255-63. https://doi.org/10.1016/J.FORECO.2017.07.005.

91. Chiatante G, Porro Z, Musacchio A, Bazzocchi A, Meriggi A. Multi-scale habitat requirements of forest bird species in a highly fragmented landscape. J Ornithol. 2019:1-16. https://doi.org/10.1007/s10336-019-01 664-9.

92. Morelli F, Pruscini F, Santolini R, Perna P, Benedetti Y, Sisti D. Landscape heterogeneity metrics as indicators of bird diversity: determining the optimal spatial scales in different landscapes. Ecol Indic. 2013;34:372-9. https://doi.org/10.1016/j.ecolind.2013.05.021.

93. Schindler S, von Wehrden H, Poirazidis K, Wrbka T, Kati V. Multiscale performance of landscape metrics as indicators of species richness of plants, insects and vertebrates. Ecol Indic. 2013;31:41-8. https://doi.org/10.1016/j. ecolind.2012.04.012

94. Asbeck T, Pyttel P, Frey J, Bauhus J. Predicting abundance and diversity of tree-related microhabitats in Central European montane forests from common forest attributes. For Ecol Manage. 2019;432:400-8. https://doi. org/10.1016/j.foreco.2018.09.043.

95. Kahl T, Bauhus J. An index of forest management intensity based on assessment of harvested tree volume, tree species composition and dead wood origin. Nat Conserv. 2014;7:15-27. https://doi.org/10.3897/na tureconservation.7.7281.

96. Van Wagner CE. Practical aspects of the line intersect method. Minister of Supply and Services Canada; 1982.

97. Basile M, Romano A, Costa A, Posillico M, Scinti Roger D, Crisci A, et al. Seasonality and microhabitat selection in a forest-dwelling salamander. Sci Nat. 2017;104(9-10):80. https://doi.org/10.1007/s00114-017-1500-6.

98. Asbeck T, Großmann J, Paillet Y, Winiger N, Bauhus J. The use of tree-related microhabitats as forest biodiversity indicators and to guide integrated forest management. Curr For Reports. 2021;7:59-68.

99. McGarigal K, Cushman SA, Ene E. FRAGSTATS; 2012.

100. Sorace A, Gustin M, Calvario E, lanniello L, Sarrocco S, Carere C. Assessing bird communities by point counts: repeated sessions and their duration. Acta Ornithol. 2000;35(2):197-202. https://doi.org/10.3161/068.035.0213.

101. Balestrieri R, Basile M, Posillico M, Altea T, Matteucci G. Survey effort requirements for bird community assessment in forest habitats. Acta Ornithol. 2017;52(1):1-9. https://doi.org/10.3161/00016454AO2017.52.1.001.

102. Wesołowski T, Czeszczewik D, Hebda G, Maziarz M, Mitrus C, Rowiński P. 40 years of breeding bird community dynamics in a primeval temperate forest (Białowieża National Park, Poland). Acta Ornithol. 2015;50(1):95-120. https:// doi.org/10.3161/00016454AO2015.50.1.010.

103. BirdLife International. IUCN Redl list for birds. 2020. www.birdlife.org. Accessed 9 Nov 2020.
104. Wesołowski T. "Lifespan" of woodpecker-made holes in a primeval temperate forest: a thirty year study. For Ecol Manage. 2011;262(9):1846-52. https://doi.org/10.1016/j.foreco.2011.08.001.

105. Wesołowski T. "Lifespan" of non-excavated holes in a primeval temperate forest: a 30 year study. Biol Conserv. 2012;153:118-26. https://doi.org/10.101 6/j.biocon.2012.04.017.

106. Martin K, Eadie JM. Nest webs: a community-wide approach to the management and conservation of cavity-nesting forest birds. For Ecol Manage. 1999;115(2-3):243-57. https://doi.org/10.1016/S0378-1127(98)004 03-4.

107. Minot EO, Perrins CM. Interspecific interference competition -- nest sites for blue and great tits. J Anim Ecol. 1986;55(1):331-50. https://doi.org/1 $0.2307 / 4712$.

108. Kullberg C, Ekman J. Does predation maintain tit community diversity? Oikos. 2000:89(1):41-5. https://doi.org/10.1034/j.1600-0706.2000.890105.x.

109. Alatalo RV, Gustafsson L, Lundberg A. Interspecific competition and niche changes in tits (Parus spp.): evaluation of nonexperimental data. Am Nat. 1986;127(6):819-34. https://doi.org/10.1086/284527.

110. Dhondt AA. Ecological and evolutionary effects of interspecific competition in tits. Wilson Bull. 1989;101:198-216.

111. Norberg RÅ, Norberg UML. Evolution of enlarged body size of coal tits Parus ater in geographic isolation from two larger competitors, the crested tit Parus cristatus and the willow tit Parus montanus, on six Scandinavian islands. Biol Open. 2015;4(11):1490-508. https://doi.org/10.1242/bio.013839.

112. Dhondt AA. Effects of competition on great and blue tit reproduction: intensity and importance in relation to habitat quality. J Anim Ecol. 2010; 79(1):257-65. https://doi.org/10.1111/j.1365-2656.2009.01624.x.

113. Alatalo RV, Gustafsson L, Linden M, Lundberg A. Interspecific competition and niche shifts in tits and the goldcrest: an experiment. J Anim Ecol. 1985; 54(3):977-84. https://doi.org/10.2307/4391.

114. Yamaura Y, Royle JA, Shimada N, Asanuma S, Sato T, Taki H, et al. Biodiversity of man-made open habitats in an underused country: a class of multispecies abundance models for count data. Biodivers Conserv. 2012; 21(6):1365-80. https://doi.org/10.1007/s10531-012-0244-z.

115. Kéry M, Royle JA. Applied hierarchical modeling in ecology. Elsevier. 2016. https://doi.org/10.1016/C2013-0-19160-X.

116. Rota CT, Ferreira MAR, Kays RW, Forrester TD, Kalies EL, McShea WJ, et al. A multispecies occupancy model for two or more interacting species. Methods Ecol Evol. 2016;7(10):1164-73. https://doi.org/10.1111/2 041-210X.12587.

117. Gelman A, Hill J. Data analysis using regression and multilevel/hierarchical models. New York: Cambridge University Press; 2007.

118. Kellner K. jagsUl; 2018.

119. Villard M-A, Trzcinski MK, Merriam G. Fragmentation effects on forest birds: relative influence of woodland cover and configuration on landscape occupancy. Conserv Biol. 1999;13(4):774-83. https://doi.org/10.1046/j.1523-1 739.1999.98059.x.

120. Oksanen J, Blanchet FG, Friendly M, Kindt R, Legendre P, McGlinn D, et al. vegan: Community ecology package. 2019. https://cran.r-project.org/packa ge=vegan .

\section{Publisher's Note}

Springer Nature remains neutral with regard to jurisdictional claims in published maps and institutional affiliations. 